\title{
1. Nature-based tourism in a Nordic context
}

\author{
Peter Fredman, Jan Vidar Haukeland, Liisa \\ Tyrväinen, Stian Stensland and Sandra \\ Wall-Reinius
}

\section{INTRODUCTION}

In a global perspective, the Nordic region is one of the prominent destinations among tourists looking for nature-based activities and experiences. The Nordic countries are typically seen as a single tourism region characterized and inspired by common ideas and values like openness, trust and sustainability. Geopolitically, they are a geographical and cultural region in Northern Europe and the North Atlantic which consists of Denmark, Finland, Iceland, Norway and Sweden, and the three autonomous regions: the Åland Islands, the Faroe Islands and Greenland (Nordic Council of Ministers, 2019a). The Nordic countries have much in common in their way of life, history, language and social structure, but the geophysical conditions show great variability. Despite the northern location, climate is milder than many other places at the same latitude due to the Atlantic Gulfstream. This also implies four distinct seasons with different temperature, light and weather conditions.

In this chapter, we describe the Nordic region as a tourist destination primarily illustrated with examples from Norway, Sweden and Finland. The east-west and north-south gradients of these countries capture many of the special features of nature-based tourism in the Nordic region. In the context of tourism, it makes sense to speak in terms of a destination rather than a region, being a key concept of institutionalized tourism. However, regardless if one takes an economic geography, marketing management, customer, or cultural oriented approach (Saraniemi and Kylänen, 2011), we believe the Nordic region has much in common also as a tourist destination. We also argue there is a common understanding of what nature-based tourism is among the Nordic countries, which can be expressed as human activities occurring when visiting nature areas outside the ordinary neighborhood (Fredman and Tyrväinen, 
2010), or put differently, where the key attraction factor is nature and key activities are based on the nature environment (Koivula and Saastamoinen, 2005). For a more in-depth discussion about definitions of nature-based tourism we refer to the Introduction to this volume.

\section{THE NORDIC REGION}

Although comprising quite small countries individually, the Nordic region is geographically the seventh largest region in the world, Greenland included (Nordic Council of Ministers, 2018). The Western, North Atlantic part (Greenland, Iceland, Faroe Islands, Western and Northern Norway) are rugged with spectacular mountain, glacier and fjord environments. Further east (Eastern Norway, Sweden and Finland), the terrain flattens out and the boreal taiga forests with many lakes and rivers characterize the landscape. The Nordic territories expand north of the Arctic Circle, where climatic conditions are more challenging, while the southern parts of Sweden and Denmark are characterized by deciduous forests and extensive agricultural lands. Iceland, located at the Mid-Atlantic Ridge, has very different geothermal conditions compared with the rest of the Nordic region, including many volcanoes and hot springs combined with glaciers, making it a very special tourist destination.

With a population of 27 million (Table 1.1), the density is only 17 inhabitants per $\mathrm{km}^{2}$, which is considerably lower compared with, for example, the European Union (118 inhabitants per $\mathrm{km}^{2}$ ) or the United States (35 inhabitants per $\mathrm{km}^{2}$ ). Most people live in urban regions, primarily in the southern and coastal parts of the countries. In this respect, there has been a dramatic shift over the last centuries. Two hundred years ago, 90 percent of the population in Sweden lived in areas classified as "rural," while today 85 percent of the population live in urban areas. Sweden has had one of the highest degrees of urbanization in Europe, while the centralization process in Norway is slower than most other industrialized countries due to more pronounced regionalization policies. In Finland, about 80 percent of the population live in densely populated areas. Like most other developed countries, life expectancy is growing, with aging populations as a result. Cultural diversity has increased in the Nordic region. Sweden, the most migration liberal country, had 19 percent foreign-born persons in 2019, a figure that has almost doubled since year 2000. The northern parts of Norway, Sweden and Finland, as well as parts of the Kola Peninsula in Russia, are also referred to as Sápmi, which includes the geographic area of the native Sami people, their heritage and languages. In Sápmi, reindeer herding is an economic activity distinct to the Sami people, also seen as an important part of Sami culture and heritage (Rydberg, 2011). 
Table 1.1 Selected statistics from the Nordic region

\begin{tabular}{l|c|c|c|c|c}
\hline & \multicolumn{1}{c}{ Denmark } & \multicolumn{1}{c}{ Finland } & \multicolumn{1}{c}{ Iceland } & Norway & Sweden \\
\hline Land area $\left(\mathrm{km}^{2}\right)$ & 42926 & 338430 & 103492 & 323808 & 447435 \\
\hline Population (million) & 5.78 & 5.53 & 0.35 & 5.30 & 10.12 \\
\hline Tourism proportion of GDP (\%) & 2.1 & 2.5 & 8.4 & 4.3 & 2.8 \\
\hline $\begin{array}{l}\text { International visitors of total } \\
\text { commercial bed-nights (\%) }\end{array}$ & 51 & 31 & 87 & 30 & 27 \\
\hline Employment from tourism & 136000 & 140000 & 25000 & 162000 & 172000 \\
\hline
\end{tabular}

Sources: Nordic Council of Ministers (2018, 2019b); Innovasjon Norge (2019); Tillväxtverket (2018); http://www.dst.dk; http://www.stat.fi; http://www.statice.is; http://www.scb.se.

\section{TRANSFORMATION OF NATURAL RESOURCE DEPENDENT ECONOMIES}

The Nordic economies have historically been based on extraction of natural resources through fisheries, forestry, mining, agriculture and more recently oil. But due to labor rationalization in production and changes in market demand, several of the economies now increasingly depend on the service industries. In Finland, for example, forests had a key economic role for many decades, making it one of the world's leading wood producers and providers of raw material for wood processing industries, while the largest share of the economy today is the service sector (59 percent of gross domestic product, GDP), followed by industry (24 percent of GDP).

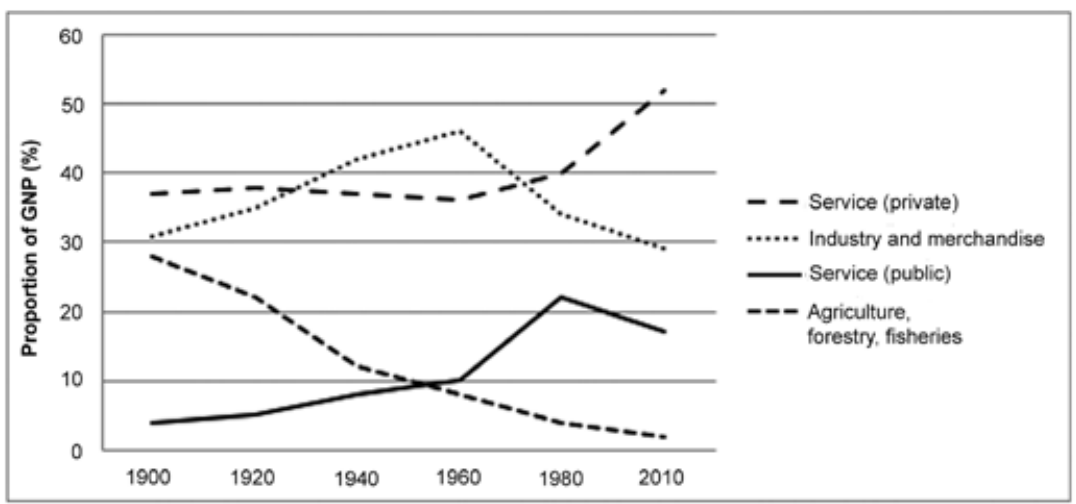

Source: Statistics Sweden.

Figure 1.1 Transformation of the Swedish economy 1900-2010 
A similar pattern is observed for Sweden (Figure 1.1). Data from Statistics Sweden show that service industries now are dominating the economy, while the share of GDP from agriculture, forestry and fisheries has decreased considerably over the last decades. Industry and merchandise sectors also show negative trends since the 1960 s, while the private service sector increases the most. This is also where we find much of the tourism industry.

Contemporary tourism polices often aim to stimulate new job opportunities in rural regions where many jobs were lost in the extractive industries (e.g. forestry, agriculture, mining) due to heavy rationalizations in the 1970s and onwards. Nature-based tourism is therefore a strategic focus area also from a regional development perspective (SOU, 2017), something even more evident in the more decentralized Norway, where several governmental white papers and tourism strategies point at profitability, year-round businesses and rural development (Nærings- og fiskeridepartementet, 2017). Recently, a more diversified view of nature-based tourism products as a basis for rural economic development has emerged, driven by, for example, increased wealth, new technologies and changes towards more experience oriented and active lifestyles (see Chapter 2 of this volume about trends in nature-based tourism).

\section{EMERGING NATURE-BASED TOURISM}

Traveling for outdoor leisure experiences has been connected to several movements, such as nationalism, romanticism, nature conservation, industrialization, environmental philosophy and well-being (e.g. Sörlin, 1999; Wall-Reinius, 2009). The mountains in the north have played, and still do, a special role in transmitting feelings of sublimity and outdoor recreation values. The scenic Norwegian landscape attracted upper-class "lords" from Great Britain who came to fish, hunt and climb mountains in the 19th century (Fjågesund and Syme, 2003; Aas et al., in press), and the German Kaiser Wilhelm visited the country's longest fjord, Sognefjorden, on a regular basis in the summer seasons up to World War I (Skotheim, 2011). This was also the period when the Norwegian Trekking Association (DNT) and the Swedish Tourist Association (STF) were founded (in 1868 and 1885 respectively) with the purpose to support opportunities for tourism, especially in mountain areas through construction of trails and cabins. Hence, while international travel paved the way for the early tourists, most of the emerging tourism was domestic.

The Nordic friluftsliv tradition also played an important role for the development of nature-based tourism in the region, and still does (Sandell and Sörlin, 2008). Norwegian polar explorers, such as Fridtjof Nansen, emphasized the social and personal benefits of outdoor recreation in the public debates of his time, and the Norwegian Outdoor Recreation Act of 1957 finally warranted 
and formalized people's right to practice a simple way of life in natural surroundings. In the 1950s and 1960s, private cars improved accessibility to natural areas and inhabitants of an ever more industrialized, urbanized and affluent society demanded a variety of tourism products, many to be consumed in natural settings. Yet another feature of the Nordic region is the number of second homes, which is among the highest per capita in Europe and has become an important driver of nature-based tourism, both economically and culturally (Adamiak et al., 2015; Larsson and Müller, 2019). The increasingly urbanized population maintains strong connections to the countryside through a second home, where outdoor recreation skills are introduced, performed and consumed.

Following technological development and economic growth of the post World War II period, tourism has gradually developed into more mature industries with significant economic and social impacts as reflected in Table 1.1. A recent summary study, commissioned by the prime minister's office, regarding the state of nature-based tourism and outdoor recreation in Finland identified significant opportunities for business development (Tyrväinen et al., 2018). To strengthen the Nordic region and ensure future sustainable growth in alignment with the 2030 United Nations sustainable development goals, the Nordic Council of Ministers has published a plan for Nordic tourism co-operation 2013-19 (Nordic Council of Ministers, 2019a). The plan will support national tourism strategies by implementing activities linked to four strategic themes: Competitive Nordics (increase the competitiveness of the tourism industry), Innovative and smart Nordics (develop the Nordics as an innovative and smart destination), Sustainable Nordics (ensure sustainable development and growth), and Attractive Nordics (make the Nordics a more attractive and competitive destination).

However, increasing numbers of long-haul travelers, especially from North America and Asia, have also raised debates about sustainability and climate impacts from tourism (Aall, 2014). For example, in 2019 the Scandinavian Mountains Airport opened at the border between Sweden and Norway, serving major ski destinations in both countries, including Norway's largest winter destination Trysil, which is certified as a "sustainable destination". Although many destinations want more visitors, there are environmentally concerned operators in the nature-based tourism sector actively promoting travelers arriving by alternative and more environmentally friendly transportation.

\section{THE SUPPLY OF NATURE-BASED TOURISM}

During the last decades, the nature-based tourism sector has flourished in many places of the Nordic region. Studies from Norway and Sweden identify approximately 3000 service providers in each country respectively, whereof 
a majority are rather small, typically two to three full-time positions with a turnover in the 100,000-200,000 Euro range (Fredman and Margaryan, 2014; Stensland et al., 2018). The products offered are diverse and up to 70 different activities are identified. In Norway, fishing is the most common product, offered by over 60 percent of all firms, while hiking and mountaineering are offered by almost 50 percent. These can be divided into the five product categories; facilitation (maps, signs, etc.), equipment rental, accommodation, guiding services and angling/hunting license. Most Norwegian firms report they are in a start-up or growth phase, indicating further expansion of the sector (Stensland et al., 2018).

In Sweden, the supply of activities is mostly water based and summer related. Guided activities in nature and accommodation are ranked as the most important business services while fishing, kayaking, canoeing and/or rafting are the most important recreation activities (Fredman and Margaryan, 2014). In Finland, there are approximately 5700 firms which base their business partly or solely on services related to nature experiences. A large share (3700 firms) provide accommodation services, while approximately 1000 enterprises offer other services (Petäjistö and Selby, 2012), which is lower compared with Norway and Sweden. ${ }^{1}$ Nature-based tourism and recreation services in Finland are estimated to employ 33,800 people, which is about 10 percent of employment in the Finnish bio-economy sector (Tyrväinen et al., 2018).

Several studies verify that nature-based tourism to a large extent is a lifestyle business in the Nordic context, whereas economic incentives have less importance (Fredman and Margaryan, 2014; Lundberg et al., 2014; Petäjistö and Selby, 2014; Stensland et al., 2018; see also Chapter 10 in this volume). Research on the success and constraints among service providers in nature-based tourism in both Norway and Sweden shows that success is typically associated with internal factors, such as commitment, competence, lifestyle and access to natural resources (Lundberg and Fredman, 2012; Stensland et al., 2014). Studies from all three countries also document that the highest concentration of nature-based tourism supply is in the western and northern parts. Hence, it appears that the more spectacular and iconic nature, such as fjords, mountains, rivers, archipelagos and northern lights, provide fodder to many of the businesses in the sector.

\section{TOURISM, NATURE PROTECTION AND INFRASTRUCTURE}

Not only have economies been transforming in the Nordic region. There was an important change in view on nature protection vis-à-vis recreation and tourism in the early 2000s. As nature-based tourism emerged as a potential source of employment and income in rural areas, the attractions of protected 
areas were also recognized. ${ }^{2}$ Evidence of this view was the Norwegian "Mountain Text" (Fjellteksten), of 2003 stating: "If we manage to protect the natural and cultural historic assets of the Norwegian mountain areas, not least in protected areas, the Government sees a large potential for increased environmentally adapted tourism in our mountain areas" (Finansdepartementet, 2003). Consequently, a National Park catchphrase - Welcome in - has been developed for Norwegian National Parks, and by 2020 all parks will have a visitor strategy in place (Miljødirektoratet, 2015).

Similarly, in 2001 the Swedish government stated that nature protection shall have a more active role for outdoor recreation opportunities and promoting nature-based tourism (Writ. 2001/02:173). A few years later the Protect, Preserve, Present program was launched by the Swedish Environmental Protection Agency where two out of six focus areas concerned outdoor recreation, tourism and information. In 2010 the Swedish parliament voted for the bill The Future of Outdoor Recreation (Prop. 2009/10:238), deciding on ten goals for outdoor recreation in Sweden, whereof two concerned sustainable regional growth through nature-based tourism and protected areas as a resource for outdoor recreation respectively. These goals are now operationalized through various outdoor recreation and tourism policies (Writ. 2012/13:51; SOU, 2017).

The policy shifts in nature conservation described above also illustrate how tourism is viewed - a personal experience in outdoor recreation and an economic avenue for places and people. The mandate managers of protected areas operate with typically include both, as recreation in the outdoors is increasingly being commercialized through nature-based tourism (Margaryan, 2017). However, since nature protection, outdoor recreation and commercial tourism belong to different political areas and ministries, challenges remain on how to best balance them in practice. Sustainable tourism in protected areas depends on access to planning resources (personnel, competence, money) both within the nature management system and across borders, that is, links to local municipalities (see Chapter 6 in this volume). Today, there are insufficient resources for visitor management at many nature conservation agencies and local planning networks for tourism development in protected areas are often not effectively institutionalized (Stokke and Haukeland, 2018).

However, new ways for the tourism sector to contribute to nature and landscape conservation have been sought in Finland. Intensive forest management targeted to timber production with clear cuts and shortened rotation cycles have negative impacts on landscapes used by tourism companies. As private owners get economic benefits from forests only from timber sales, new types of incentives are needed to compensate landowners of the economic losses of timber values for securing recreational values in the landscape. Studies show that tourists are quite willing to economically contribute locally to nature and 
landscape conservation (Tyrväinen et al., 2014), while for tourism entrepreneurs this type of corporate responsibility is new and attitudes towards contributing vary, although many companies see forest landscapes as important for their businesses (Mäntymaa et al., 2019). Private landowners are relatively willing to safeguard landscape and biodiversity values if timber production losses are compensated (Mäntymaa et al., 2018; Tyrväinen et al., 2020).

While protected areas become increasingly important for tourism, a growing interest in outdoor recreation also leads to more public investments in trails for different activities (hiking, biking, snowmobiling, etc.), visitor centers, shelters, information boards, signposting, garbage cans, toilets, parking areas, marinas, and so on. In Finland, for example, Metsähallitus (the Forest Administration) manages vast recreational infrastructure in National Parks and other protected areas that is financed through tax funds. Such facilities have proven to be very important for the visitor experience (Wall-Reinius and Bäck, 2011; Haukeland et al., 2012), and function as tourist attractions in themselves (Godtman Kling et al., 2017), such as the Swedish "Kungsleden" (Kings Trail) or the several St. Olav ways - pilgrim paths to Trondheim, Norway. Infrastructure can also be an efficient management tool in land use conflicts. Godtman Kling et al. (2019) showed that trails reduce and prevent conflicts if they function as facilitators for collaboration among stakeholders, and thus enhance the possibilities for dialogue and negotiations in the Swedish mountains. Important to notice in this context is also the philosophical stream of Nordic, primarily Norwegian, outdoor recreation culture (friluftslivskultur) that opposes most forms of facilitation for visitors in natural areas. This tradition has its roots in the eco-philosophy movement (e.g. Næss, 1993), an ideology that can also be tracked forward to contemporary adventure tourism concepts (Varley and Semple, 2015).

\section{THE RIGHT OF PUBLIC ACCESS}

Access to the countryside is fundamental for recreation and tourism in the outdoors (Kaltenborn et al., 2001; Williams, 2001; Manning, 2011). While some activities are more dependent upon exclusive rights to resources (e.g. hunting, fishing), research from Sweden shows that most activities supplied by the nature-based tourism sector benefit from an open access regime (Fredman et al., 2012). Access to the countryside can in principle be provided in three ways - private ownership of land and water areas, access to publicly owned areas, or access to private and/or publicly owned areas that can be utilized for recreation (Sandell and Fredman, 2010). The latter type of access - the public's access to areas for recreation without asking the landowner for permission - is known as the Right of Public Access. This right has arguably played a significant role also for the development of nature-based tourism in the Nordic region. 
In Norway, the Right of Public Access (allemannsretten) is embedded in the above-mentioned Outdoor Recreation Act (Friluftsloven). The Act permits year-round unrestricted foot access for everyone in wilderness (non-cultivated) areas on both public and private lands. In Sweden, the Right of Public Access is even mentioned in the Constitution, although its content is not directly specified. In principle, it can be viewed as a "free space" for recreation and a restriction to ownership rights, where the boundaries primarily include economic interests, privacy, nature conservation and the use and change of the landscape. In Finland, similar public access rights (jokamiehen oikeudet) are also part of the constitution and imply several obligations for the visitor to act in a cautious manner so that no unacceptable damage or disadvantage arises to nature, landowners and other recreationalists.

However, tourism operating under an open access regime is not without challenges. The Right of Public Access is a traditional right that emerged in sparsely populated regions, and commercial nature-based tourism is not explicitly included. This has caused a debate around commercial use and public access in several Nordic countries. Nordic associations for outdoor recreation have also campaigned for the inclusion of the Right of Public Access in UNESCO's list of intangible cultural heritage, which has raised discussions about the possible challenges linked with increased tourism (Øian et al., 2018).

\section{GOVERNING IMPACTS FROM NATURE-BASED TOURISM}

Tourism can potentially provide both positive and negative effects with respect to all three pillars of sustainability, and perhaps even more so looking at nature-based tourism in peripheral areas where natural environments and local communities are more exposed to external impacts (Hall and Boyd, 2005). While much of the tourism policies in the Nordics traditionally have focused on growth and regional development (Hall et al., 2009), challenges associated with over-tourism have more recently put environmental and social topics on the agenda (SOU, 2017). The combination of an open access landscape and increasing tourism numbers has caused special challenges to sustainable tourism in the Nordics. A review of policy instruments for sustainable nature-based tourism published by the Nordic Council of Ministers recommends more focus on public-private collaboration, adaptive management strategies (zoning, traffic regulations, information, guiding) and dispersion of visitors through marketing and infrastructures (Øian et al., 2018). Economic instruments, such as user fees and concessions, involve many challenges and should be balanced against costs for administration and protection of the Right of Public Access. 
Governing tourism impacts is not an easy task given the many stakeholders involved and complexity of the sector. In Norway, most political initiatives occur on regional and/or local levels, while tourism has a rather weak position at the national level. There is a lack of political support for managing common-pool resources by tourist taxation among the central authorities and insufficient means to uphold necessary facilities for visitors. More recently some state initiatives have been witnessed such as the inauguration of national tourist trails (nasjonale turiststier) and a visitor strategy for the National Parks (Miljødirektoratet, 2015). The local municipalities in Norway play an important role in obtaining, safeguarding and facilitating nature areas for outdoor recreation activities. A nationwide inter-municipal membership organization (Friluftsrådenes Landsforbund) supports collaboration between local communes. Negotiating and signing agreements with landowners are essential tasks for facilitating natural sites and areas for outdoor recreation interests. Similar fragmented, but more centralized, systems are found in Sweden and Finland. A recurrent theme is that management (and protection) of natural and cultural resources are governed by different ministries and agencies than those responsible for promotion of tourism (Tyrväinen et al., 2018) - a divide that can be a major challenge for the future development of sustainable nature-based tourism (Laven et al., 2015).

\section{CONCLUDING REMARKS}

This chapter has highlighted some of the key characteristics of nature-based tourism in a Nordic context. Similar conditions are found in other regions around the world being rich in natural resources and popular among nature-seeking visitors. What makes the Nordics a special place are its high accessibility and developed infrastructure, relatively mild climate for its location and open societies. These values cannot be taken for granted in an increasingly changing world, driven by economic incentives and protectionism. Several of the megatrends affecting nature-based tourism, such as climate change, technology, pandemics and political instability (Elmahdy et al., 2017), can drastically challenge tourism opportunities in a short time. Resilience of natural and social-cultural systems will therefore be of outmost importance for the sustainable development of nature-based tourism (see Chapter 5 in this volume). Finally, it is also interesting to observe how values of the long-standing Nordic friluftsliv tradition are increasingly recognized by the commercial adventure tourism sector, operating in global markets across many segments (Varley and Semple, 2015; Mykletun, 2018). This gives hope for a deeper connection between tourism and nature, which can be yet another contribution to a more sustainable future. 


\section{NOTES}

1. Note that the Norwegian and Swedish studies did not include firms with accommodation only, which explains some of the differences compared to Finland.

2. In Sweden, several of the National Parks had a ban against commercial activities written into the management plan until the early 2000 s.

\section{REFERENCES}

Aall, C. (2014), 'Sustainable tourism in practice: Promoting or perverting the quest for a sustainable development?', Sustainability, 6, 2562-83.

Aas, Ø., S. Stensland and S. Baardsen (In press), 'Norwegian salmon fishing tourism. Only a resource-based tourism product?', in A.L. Svalastog and D. Muller (eds), Tourism Resources, Cambridge Scholars Publishing.

Adamiak, C., M. Vepsäläinen, A. Strandell et al. (2015), 'Second home tourism in Finland - perceptions of citizens and municipalities on the state and development of second home tourism', Reports of the Finnish Environment Institute, 22en/2015.

Elmahdy, Y.M., J.V. Haukeland and P. Fredman (2017), 'Tourism megatrends, a literature review focused on nature-based tourism', Norwegian University of Life Sciences, MINA fagrapport 42.

Finansdepartementet (2003), 'Tilleggsbevilgninger og omprioriteringer i statsbudsjettet medregnet folketrygden 2003', St.prp. nr. 65 (2002-2003).

Fjågesund, P. and R.A. Syme (2003), The Northern Utopia: British Perceptions of Norway in the Nineteenth Century, Amsterdam and New York: Rodopi.

Fredman, P. and L. Margaryan (2014), 'The supply of nature based tourism in Sweden. A national inventory of service providers', Mid Sweden University, ETOUR, report 2014:1.

Fredman, P. and L. Tyrväinen (2010), 'Frontiers in nature-based tourism', Scandinavian Journal of Hospitality and Tourism, 10 (3), 177-89.

Fredman, P., S. Wall-Reinius and A. Grundén (2012), 'The nature of nature in nature-based tourism', Scandinavian Journal of Hospitality and Tourism, 12 (4), 289-309.

Godtman Kling, K., P. Fredman and S. Wall-Reinius (2017), 'Trails for tourism and outdoor recreation: A systematic literature review', Tourism, 65 (4), 488-508.

Godtman Kling, K., A. Dahlberg and S. Wall-Reinius (2019), 'Negotiating improved multifunctional landscape use: Trails as facilitators for collaboration among stakeholders', Sustainability, 11 (13), 3511.

Hall, C.M. and S. Boyd (2005), Nature-based Tourism in Peripheral Areas. Development or Disaster? Clevedon, UK: Channel View Publications.

Hall, C.M., D.K. Müller and J. Saarinen (2009), Nordic Tourism: Issues and Cases, Aspects of Tourism, Clevedon, UK: Channel View Publications.

Haukeland, J.V., B. Grue and K. Veisten (2012), 'Turning national parks into tourist attractions: Nature orientation and quest for facilities', Scandinavian Journal of Hospitality and Tourism, 10 (3), 248-71.

Innovasjon Norge (2019), Nøkkeltall for norsk turisme 2018, Rapport.

Kaltenborn, B., H. Haaland and K. Sandell (2001), 'The public right of access some challenges to sustainable tourism development in Scandinavia', Journal of Sustainable Tourism, 9 (5), 417-33. 
Koivula, E. and O. Saastamoinen. (2005), 'Perspectives on nature-based tourism and its future', Communications of University of Joensuu, Faculty of Forestry, 165. [in Finnish]

Larsson, L. and D.K. Müller (2019), 'Coping with second home tourism: Responses and strategies of private and public service providers in western Sweden', Current Issues in Tourism, 22 (16), 1958-74.

Laven, D., S. Wall-Reinius and P. Fredman (2015), 'New challenges for managing sustainable tourism in protected areas: An exploratory study of the European Landscape Convention in Sweden', Society and Natural Resources, 28 (10), 1126-43.

Lundberg, C. and P. Fredman (2012), 'Critical success factors and constraints among nature-based tourism entrepreneurs', Current Issues in Tourism, 15 (7), 649-71.

Lundberg, C., P. Fredman and S. Wall-Reinius (2014), 'Going for the green? The role of money among nature-based tourism entrepreneurs', Current Issues in Tourism, 17 (4), 373-80.

Manning, R.E. (2011), Studies in Outdoor Recreation. Search and Research for Satisfaction, Corvallis, OR: Oregon State University Press.

Margaryan, L. (2017), 'Commercialization of nature through tourism', Doctoral thesis in tourism studies, Mid Sweden University, Faculty of Human Sciences.

Miljødirektoratet (2015), 'Veileder for besøksforvaltning i norske verneområder', Veileder M-415|2015, Trondheim.

Mykletun, R.J. (2018), 'Adventure tourism in the North - six illustrative cases', Scandinavian Journal of Hospitality and Tourism, 18 (4), 319-29.

Mäntymaa, E., A. Juutinen, L. Tyrväinen and M. Kurttila (2018), 'Participation and compensation claims in voluntary forest landscape conservation: The case of the Ruka-Kuusamo tourism area, Finland', Journal of Forest Economics, 33 (2018), $14-24$.

Mäntymaa, E., L. Tyrväinen, A. Juutinen and M. Kurttila (2019), 'Importance of forest landscape quality for companies operating in nature-based tourism areas', Land Use Policy, https://doi.org/10.1016/j.landusepol.2019.104095.

Nordic Council of Ministers (2018), 'Nordic Statistics 2018', ANP 2018:819, Copenhagen.

Nordic Council of Ministers (2019a), 'Plan for Nordic Tourism co-operation 2019-2023', PolitikNord 2019:727, Copenhagen.

Nordic Council of Ministers (2019b), 'Nordic Tourism Policy Analysis', Nord 2019:008, Copenhagen.

Nærings- og fiskeridepartementet (2017), 'Opplev Norge - unikt og eventyrlig', Meld. St. 19 (2016-2017).

Næss, A. (1993), Ecology, Community and Lifestyle: Outline of an Ecosophy, Cambridge: Cambridge University Press.

Petäjistö, L. and A. Selby (2012), 'Luontomatkailun yritystoiminta Suomessa', Working Papers of the Finnish Forest Research Institute 246. [in Finnish]

Petäjistö, L. and A. Selby (2014), 'Nature-based tourism and outdoor recreation as entrepreneurship', in L. Tyrväinen, M. Kurttila, T. Sievänen and S. Tuulentie (eds), Well-being from Forests, Helsinki: Finnish Literature Association, Kirjokansi 90. [in Finnish]

Prop. 2009/10:238, 'Framtidens friluftsliv', Regeringens proposition.

Rydberg, T. (2011), 'Landskap, territorium och identitet i Sapmié: Exemplet Handölsdalens sameby', Licentiate thesis, Uppsala University, Uppsala. 
Sandell, K. and P. Fredman (2010), 'The Right of Public Access: Opportunity or obstacle for nature based tourism in Sweden?', Scandinavian Journal of Hospitality and Tourism, 10 (3), 291-309.

Sandell, K. and S. Sörlin (2008), Friluftshistoria - från 'härdande friluftslif' till ekoturism och miljöpedagogik: Teman $i$ det svenska friluftslivets historia, Stockholm: Carlssons bokförlag.

Saraniemi, S. and M. Kylänen (2011), 'Problematizing the concept of tourism destination: An analysis of different theoretical approaches', Journal of Travel Research, $50(2), 133-43$.

Skotheim, S. (2011), Keiser Wilhelm i Norge, Oslo: Spartacus forlag.

SOU (2017), Ett land att besöka. En samlad politik för hållbar turism och växande besöksnäring, Betänkande av Utredningen Sveriges besöksnäring, Statens Offentliga Utredningar, SOU 2017:95.

Stensland, S., K. Fossgard, J.C. Apon et al. (2014), 'Naturbaserte reiselivsbedrifter i Norge. Frekvens- og metoderapport', Norges miljø- og biovitenskapelige universitet, Institutt for naturforvaltning, INA fagrapport 25.

Stensland, S., K. Fossgard, B. Hansen et al. (2018), 'Naturbaserte reiselivsbedrifter i Norge. Statusoversikt, resultater og metode fra en nasjonal spørreundersøkelse', Norges miljø- og biovitenskapelige universitet, Fakultet for miljøvitenskap og naturforvaltning. MINA fagrapport 52 .

Stokke, K.B. and J.V. Haukeland (2018), 'Balancing tourism development and nature protection across national park borders - a case study of a coastal protected area in Norway', Journal of Environmental Planning and Management, 61 (12), 2151-65.

Sörlin, S. (1999), 'The articulation of territory: Landscape and the constitution of regional and national identity', Norsk geografisk Tidskrift, 53, 103-11.

Tillväxtverket (2018), 'Fakta om Svensk turism'.

Tyrväinen, L., E. Mäntymaa, A. Juutinen, M. Kurttila and V. Ovaskainen (2020), 'Private landowners' preferences for trading forest landscape and recreational values: A choice experiment application in Kuusamo, Finland', Land Use Policy, https://doi.org/10.1016/j.landusepol.2020.104478.

Tyrväinen, L., E. Mäntymaa and V. Ovaskainen (2014), 'Demand for enhanced forest amenities in private lands: The case of the Ruka-Kuusamo tourism area, Finland', Forest Policy and Economics, 47, 4-13.

Tyrväinen, L., T. Sievänen, H. Konu, T. Anja, K. Aapala and O. Ojala (2018), 'How to develop nature-based recreation and tourism in Finland?', Policy Brief, Valtionneuvoston selvitys- ja tutkimustoiminta 2/2018. [in Finnish]

Varley, P. and T. Semple (2015), 'Nordic slow adventure: Explorations in time and nature', Scandinavian Journal of Hospitality and Tourism, 15 (1-2), 73-90.

Wall-Reinius, S. (2009), 'A ticket to National Parks? Tourism, railways and the establishment of National Parks in Sweden', in W. Frost and C.M. Hall (eds), Tourism and National Parks. International Perspectives on Development, Histories and Change, London: Routledge, pp. 184-96.

Wall-Reinius, S. and L. Bäck (2011), 'Changes in visitor demand: Inter-year comparisons of Swedish hikers' characteristics, preferences and experiences', Scandinavian Journal of Hospitality and Tourism, 11 (1), 38-53.

Williams, D.R. (2001), 'Sustainability and the right to roam: International differences in public rights (and responsibilities) to nature', Journal of Sustainable Tourism, 9 (5), 361-71.

Writ. 2001/02:173, ‘En samlad naturvårdspolitik', Regeringskansliet, Stockholm.

Writ. 2012/13:51, ‘Mål för friluftspolitiken', Regeringskansliet, Stockholm. 
Øian, H., P. Fredman, K. Sandell, A.D. Sæpórsdóttir, L. Tyrväinen and F.S. Jensen (2018), 'Tourism, nature and sustainability: A review of policy instruments in the Nordic countries', Nordic Council of Ministers, TemaNord, 2018:534, Copenhagen. 